\title{
TEACHING AND LEARNING WRITING SKILLS IN A TECHNOLOGICAL AGE: A SELECTIVE MAPPING OF WRITING APPS ONTO A STRUCTURED MODEL OF THE WRITING PROCESS
}

\author{
Jeroen Lievens ${ }^{1}$ \\ ${ }^{1} \mathrm{KU}$ Leuven (BELGIUM)
}

\begin{abstract}
Academic writing is a very complex process, as it relies on and integrates several actions that already in themselves require a level of expertise, proficiency and higher-order thinking skills (e.g. searching the literature, gathering and analysing data, structuring content, applying intricate sets of (language) rules and (editing) standards etc.). It comes as no surprise, therefore, that many tools and apps have been developed expressly with the purpose of supporting both learners and teachers of academic writing. However, the current offer is so large that the writing practitioner, either learner or teacher, struggles to identify which app or tool is useful at which stage in the complex process that is writing - or teaching writing. This paper describes a stocktaking effort that aimed to chart useful apps and tools and map them onto a structured model of the writing process.
\end{abstract}

Keywords: Innovation, technology, higher education, edtech, academic writing.

\section{INTRODUCTION}

Writing is a crucial skill in almost any field of study, both as a means for developing higher-order thinking skills and as the prevailing instrument in (inter)disciplinary communication. At the same time, writing is a deeply challenging activity that involves an intricate interplay of a variety of abstract cognitive processes and skills such as logical, reflective, metacognitive and evaluative skills, language proficiency, lay-outing skills and psycho-emotional attitudes.

Being both a crucial and complex (academic) activity, writing is often targeted by tool developers who are now offering a profusion of software applications such as prodding tools, spelling and grammar checkers, plagiarism detectors, structuring and visualization tools, platforms for collaborative writing and so on. The large amount and wide range of tools make it difficult for students and teachers alike to navigate the technological options on offer. Which tools are useful, to which didactic end and in which stage of the writing process?

This paper aims to, firstly, to chart the available tools, secondly, to assess them on didactic affordance (using Puentedura's SAMR-model [1] and the "seven affordances" model by Cope \& Kalantzis [2]) and finally, to map these tools onto a structured model of the writing process (the "spinner" model by Haas [3]).

\section{METHODOLOGY}

The first surveying step was executed through a study of the literature, an analysis of dedicated online platforms (such as EmergingEdTech [4], Appsakee [5] and Touch2Learn ${ }^{1}$ [6]) and of the broader digital market sphere. The resulting list of tools and apps was then critically evaluated on didactic affordance on the basis of Ruben Puentedura's SAMR-model and the "seven affordances" model by Mary Cope and Bill Kalantzis. Only those apps and tools that help meet the "transformative" bar set by Puentedura and, therefore, help make (some of) Cope \& Kalantzis' didactic affordances a classroom reality were held back. To help practitioners - both learners and teacher of (academic) writing - navigate this selection of tools and apps, the collected tools were individually positioned onto a well-structured and fine-grained model of the writing process, which was gleaned from writing researcher Sarah Haas. The

\footnotetext{
${ }^{1}$ Touch2Learn was an interdisciplinary team project funded by the OOF (Onderzoeks Ontwikkelings Fonds), KU Leuven and led by Jeroen Lievens. The project's goal was to chart and unlock the potential of handheld devices for higher education. The project resulted in the website www.touch2learn.be and in several publications, among which [7-8].
} 
resulting map was then offered up for critical analysis to the "Expert meeting" of NACV, the Dutch Network for Academic Communication Skills, in February 2018, Delft (The Netherlands).

\subsection{The SAMR-model}

Educational researcher Ruben Puentedura developed a four-part model to differentiate between uses of ICT in education (see Fig. 1). He distinguishes between Substitution, Augmentation, Modification and Redefinition, with the former being less innovative than the latter.

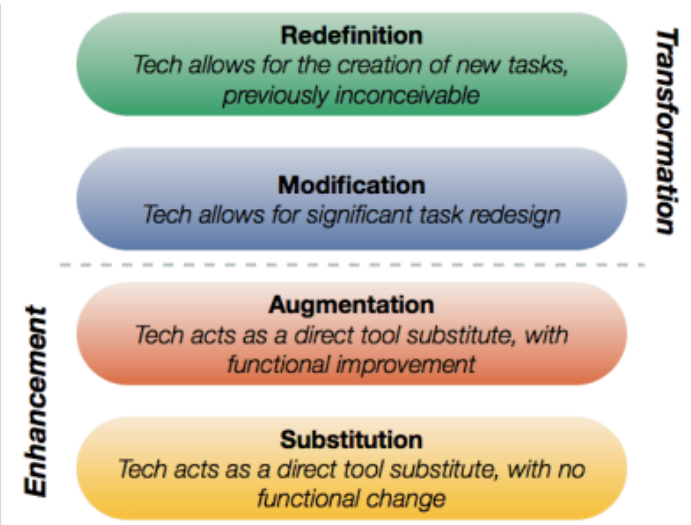

Figure 1. The SAMR-model by Ruben Puentedura [1].

Below the dotted line, the use of technology does not make a significant difference in the educational practice: technology simply substitutes for existing tools or perhaps adds some functionality (Augmentation), but it does not fundamentally change the teaching practice. An example is using Kahoot for quizzing your students: it substitutes for quizzing your students orally or in writing, and it adds the functionality of a ranking but it does not change the essence of the teaching approach. Kahoot is new technology and it may well be experienced as an "enhancement" of classroom practices but it fits comfortably within a traditional conception of learning that focuses on knowledge, drill and testing.

Above the dotted line, tech allows for significant task redesign (Modification) or even allows for the creation of new tasks that were previously inconceivable (Redefinition). It is interesting to note how the keyword below in the "transformative" field is "task", whereas it is "tool" below the dotted line. The word "task" conjures up the notion of task-based or task-oriented teaching and learning, in which the teacher sets a challenging task for students while providing just the amount of support needed for the student or the team to succeed [9-10]. In Bloom's taxonomy, the cognitive functions to which the students are challenged are analysis, evaluation and creation, whereas Substitution and Augmentation are more effective for practicing lower-order thinking skills such as remembering or understanding.

\subsection{The seven affordances model}

Bill Cope and Mary Kalantzis, well-known from their engagement within the New London Group and as co-founders of the influential notion of "multiliteracies", developed a model to help identify and label the affordances of using technology in education (see Fig. 2). The model urges educators to make their intuitions and expectations about their use of ICT in education explicit and to take their routine didactic practices into the arena of critical reflection and evaluation. 


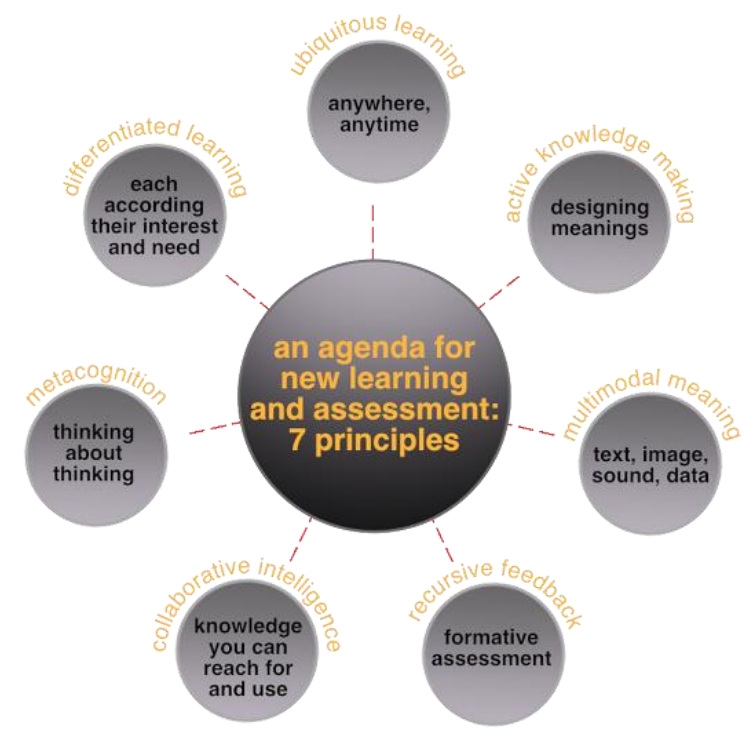

Figure 2. The seven affordances model by Cope \& Kalantzis [2].

Apps and tools that rise to Puentedura's "transformative" bar tend to help achieve several of these affordances, as challenging tasks are prone to encouraging ubiquitous learning, active knowledge making, multimodal meaning, recursive feedback, collaborative intelligence, metacognition and differentiated learning. (An applied example of these affordances will be developed in the Discussion section).

\subsection{The Spinner model}

Writing researcher Sarah Haas developed a model of the writing process, called the "spinner model" (see Fig. 3). It describes several "modes" in the writing process, with each "mode" consisting out of several possible "moves" and Haas argues that, as a writer, you can spin purposefully, though not necessarily sequentially, from one mode to the other. The model below shows the separated "modes" as yet, for clarity's sake, without the attendant "moves".

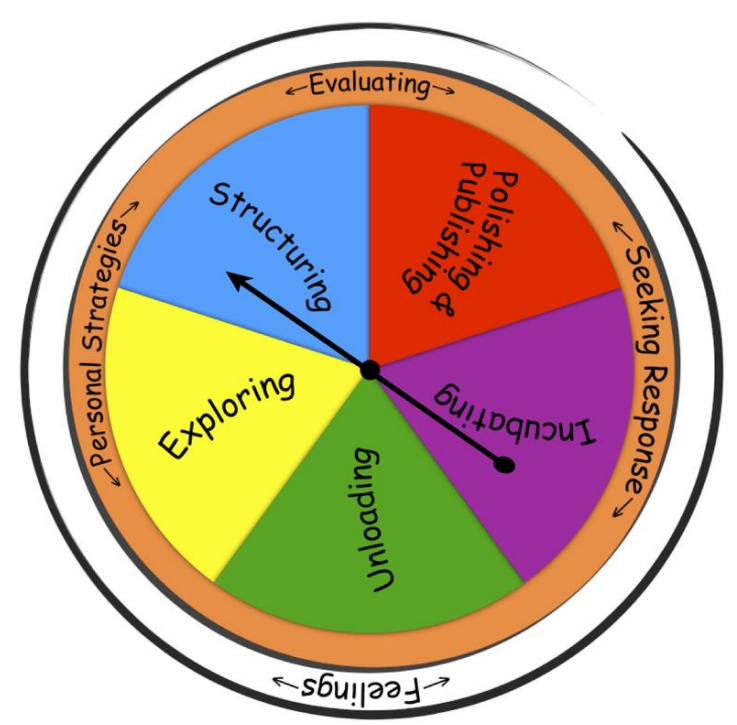

Figure 3. The spinner model by Haas [3].

It is onto this model, be it in a slightly adapted version, that the selected writing apps were mapped. To facilitate the mapping process, a spreadsheet was developed which was then visualized using Prezi. 


\section{RESULTS}

For the purpose of this mapping effort, the model by Haas was slightly adapted: the "structuring" mode was renamed into the "structuring and scribing" mode (with "scribing" as the more form-conscious pendant to the "scribbling" move in the "unloading" mode) and the outer circles were redubbed into "Collaborating on writing" and "Teaching writing". Fig. 1 shows the overall Prezi map ${ }^{2}$ and Tables 1 to 6 show the "moves" within each mode or circle with attendant apps or tools.

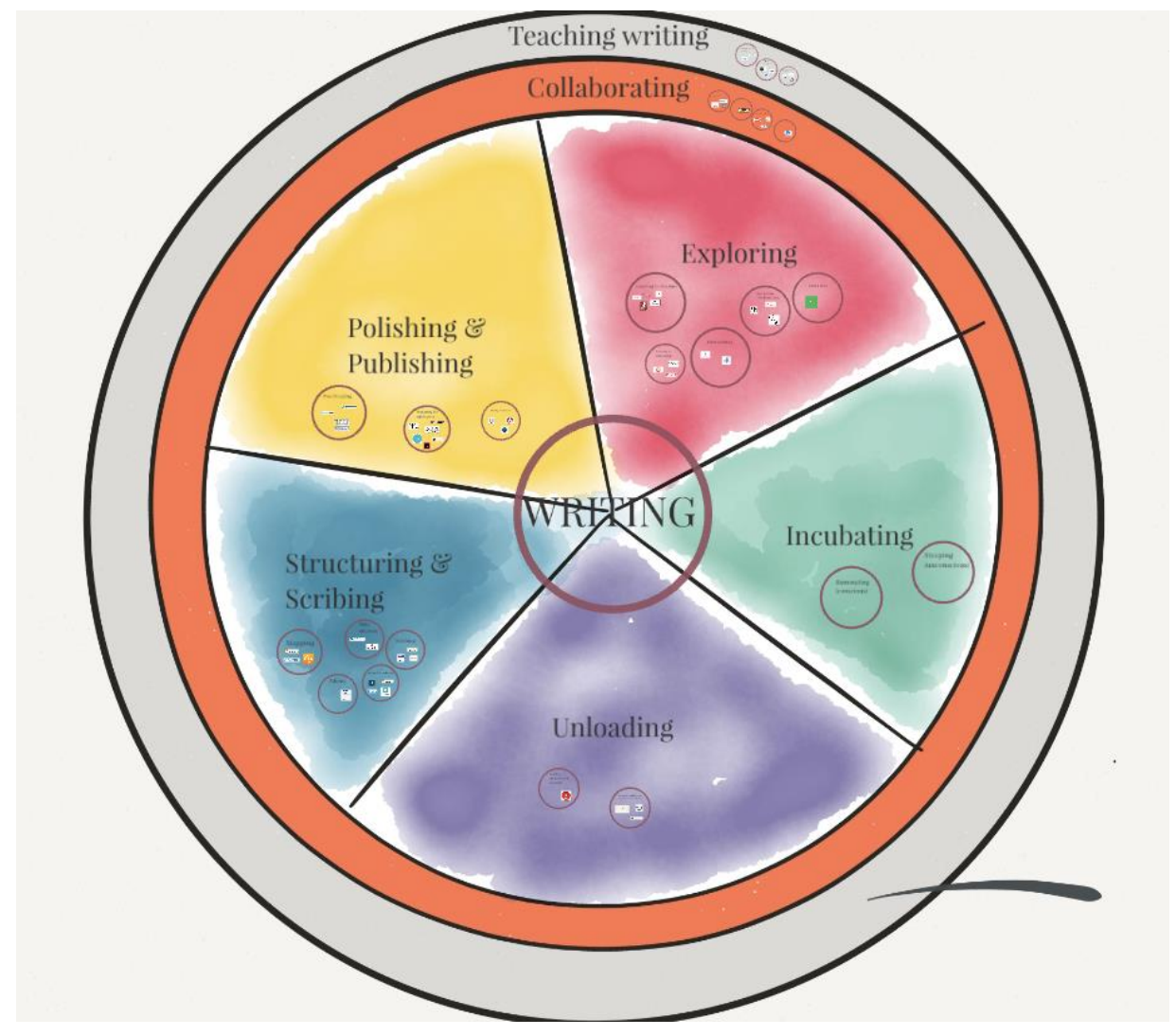

Figure 4: A screenshot of the integrated Prezi map.

Table 1. The "moves" within the "exploring" mode with attendant tools or apps.

\begin{tabular}{l|c|c|c|c|c}
\hline \hline $\begin{array}{l}\text { Searching } \\
\text { for literature }\end{array}$ & $\begin{array}{c}\text { Reading and } \\
\text { annotating }\end{array}$ & Brainstorming & $\begin{array}{c}\text { Gathering } \\
\text { data }\end{array}$ & $\begin{array}{c}\text { Freewriting } \\
\text { and prodding }\end{array}$ & $\begin{array}{c}\text { Taking } \\
\text { notes }\end{array}$ \\
\hline JStor & Nook & Padlet & Google Forms & 750 Words & Evernote \\
\hline WolframAlpha & Perusall & Stormboard & SurveyMonkey & $\begin{array}{c}\text { The Most } \\
\text { Dangerous } \\
\text { Writing app }\end{array}$ & \\
\hline Google Books & iBooks & & & ilys & \\
\hline $\begin{array}{l}\text { Google } \\
\text { Scholar }\end{array}$ & & & & & \\
\hline DOAJ & & & & & \\
\hline \hline
\end{tabular}

\footnotetext{
${ }^{2}$ The Prezi map is publicly available at http://prezi.com/uehbovdzj_ot/?utm_campaign=share\&utm_medium=copy.
} 
Table 2. The "moves" within the "structuring and scribing" mode with attendant tools or apps.

\begin{tabular}{l|c|c|c|c}
\hline \hline Mapping & Analyzing data & Scribing & $\begin{array}{c}\text { Making charts } \\
\text { and graphs }\end{array}$ & Editing \\
\hline Draw.io & Maxqda & Scrivener & Creately & $\begin{array}{c}\text { The Hemingway } \\
\text { app }\end{array}$ \\
\hline Mindmeister & Atlas.ti & $\begin{array}{c}\text { Manchester phrase } \\
\text { bank }\end{array}$ & Draw.io & \\
\hline Pureflow & Google Sheets & Thesaurus.com & Gliffy & \\
\hline & & & Piktochart & \\
\hline
\end{tabular}

Table 3. The "moves" within the "polishing and publishing" mode with attendant tools or apps.

\begin{tabular}{l|c|c|c}
\hline Proofreading & $\begin{array}{c}\text { Preparing for } \\
\text { publication }\end{array}$ & $\begin{array}{c}\text { Adding } \\
\text { references }\end{array}$ & $\begin{array}{c}\text { Detecting } \\
\text { plagiarism }\end{array}$ \\
\hline Grammarly & Jutoh & RefMe & Turnitin \\
\hline PaperRater & Pressbooks & Mendeley & Ephorus \\
\hline & Latex & Endnote & \\
\hline & InDesign & Zotero & \\
\hline & Scrivener & & \\
\hline
\end{tabular}

Table 4. The "moves" within the "unloading" mode with attendant tools or apps.

\begin{tabular}{l|c}
\hline \hline Babbling & Scribbling \\
\hline Dictaphone & Ommwriter \\
\hline & Calmly writer \\
\hline & My writing spot \\
\hline & \\
\hline
\end{tabular}

Table 5. The "moves" within the "collaborating on writing" circle with attendant tools or apps.

\begin{tabular}{l|c|c|c}
\hline \hline $\begin{array}{l}\text { Collaborative } \\
\text { brainstorming } \\
\text { and } \\
\text { argumentation }\end{array}$ & $\begin{array}{c}\text { Collaborative } \\
\text { sketching }\end{array}$ & $\begin{array}{c}\text { Organizing a } \\
\text { group process }\end{array}$ & $\begin{array}{c}\text { Writing/scribing/editing } \\
\text { collaboratively }\end{array}$ \\
\hline Tricider & Stoodle & Trello & Google Docs \\
\hline ProConlt & & WorkFlowy & \\
\hline Padlet & & Wuala & \\
\hline & & & \\
\hline
\end{tabular}


Table 6. The "moves" within the "teaching writing" circle with attendant tools or apps.

\begin{tabular}{l|c|c}
\hline $\begin{array}{l}\text { Making clips \& } \\
\text { tutorials }\end{array}$ & Giving feedback & $\begin{array}{c}\text { Interacting with } \\
\text { the class in real- } \\
\text { time }\end{array}$ \\
\hline ShowMe & Kaizena & Socrative \\
\hline ExplainEverything & Revisely & Formative \\
\hline Camtasia & Google Docs & Zeetings \\
\hline
\end{tabular}

\section{DISCUSSION}

The map was presented to NACV, the Dutch Network for Academic and Communicative Skills in 2018, at the yearly "Expert meeting" (Delft, The Netherlands), where it was favourably received. The NACV experts decided to join the effort and collaborate on the further development of the map, of which both the spreadsheet and Prezi version was shared with the meeting participants. Since then, the map can be considered to be a collaborative effort that is sustained by practitioners in the field of academic communication instruction in higher education in the Netherlands and in Flanders.

To demonstrate the practical usefulness of the map, I will briefly develop an applied example from my own teaching practice. I am teaching academic communication skills to industrial engineering students, who, typically, do not consider communication skills as part of their core competencies. Since direct instruction on academic writing fails to trigger interest and motivation, I set them the task to survey the workplace on the importance of communication skills for engineers using a (standardized) questionnaire and additional qualitative research methods (interviews, literature research,...). ${ }^{3}$ The students then analyse the spreadsheet with the data that result from the questionnaire, they generate graphs and finally, they write out the procedure and results in an academic paper. To show just one example of a research finding, Fig. 5 visualizes the results to the question: which percentage of your daily working time do you spend communicating actively, either orally or in writing?

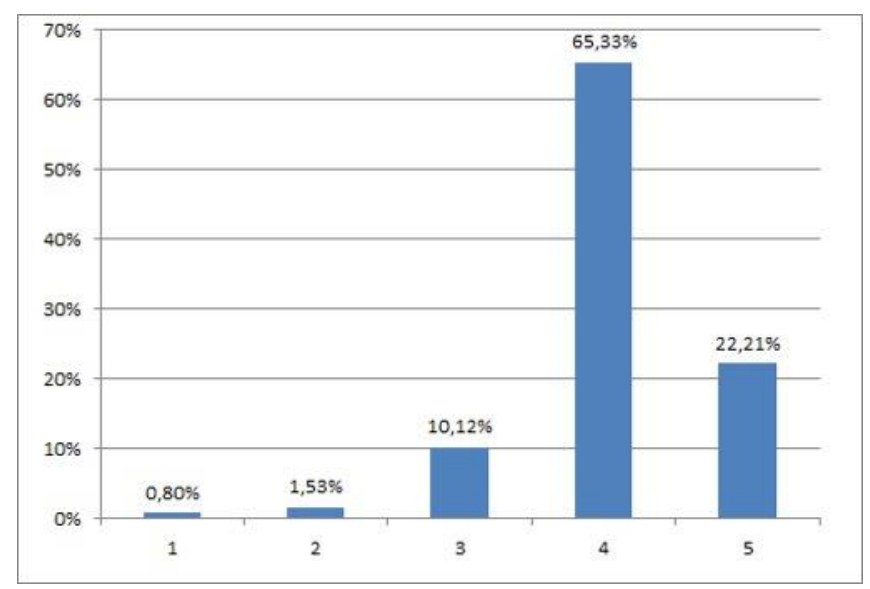

Figure 5. The percentage of time engineers spend communicating in the workplace, with " 1 " on the $X$ axis corresponding to "0-20\%", 2 to "20-40\%", 3 to " $40-60 \%$ ", 4 to "60-80" \% and 5 to " $80-100 \%$ ", and with respondents (\%) on the $Y$-axis.

Apparently, a majority of engineers spend in between $60-80 \%$ of their work day while communicating actively. This given alone is a real eye-opener for the engineering students. Other results go on to show

\footnotetext{
${ }^{3}$ The approach is described in greater detail in [11]. Over the past 5 years, around 1500 professional engineers have completed the questionnaire.
} 
that about half of that time is spent on written communication, which serves to boost motivation for academic writing courses.

This approach is an example of task-based learning and teaching and it is an approach that would have close to impossible to implement without the use of technology. Therefore, the task meets the requirements for "transformation" in the SAMR-model. Also, the task-based approach makes many of the "seven affordances" a practical reality or, at least, facilitates their implementation: a) active knowledge making: the students are not told that communication skills are important for engineers but they discover it themselves; $b$ ) multimodal meaning: the students write e-mails to invite engineers to complete the questionnaire, they work with quantitative data and with qualitative data (e.g. obtained through interviews), they make graphs, tables and charts; c) recursive feedback: contact time in class is conceived of as writing labs during which students write in Google Docs that are shared in real time with group members and with the teacher, who provide real-time feedback; e) collaborative intelligence: students work in pairs in the writing labs and submit the final paper as a team consisting out of three pairs; f) metacognition: students reflect upon their own thinking: How do their preconceptions about the importance of communication correspond to the real data? How should they give shape to their learning trajectory in function of their career goals?; g) differentiated learning: on the learning platform, a lot of learning sources are available which each can use according to his/her own need; h) ubiquitous learning: the learning trajectory involves a range of teaching materials that can be accessed at any time, any place (e.g. a video library with self-made knowledge clips on referencing, grammatical topics, spelling topics,...).

The map of tools and apps shown in Fig. 4 helps teacher and students alike with identifying which tools can be used in the execution of this complex, academic research and writing task. For instance, in the exploring mode, Google Scholar and Evernote can be used to search the literature and take notes, while Google forms can be used for the questionnaire (see Table 1). In the "structuring and scribing mode", data can be analyzed using Google sheets and the structure of the paper can be mapped out using Mindmeister. In the "polishing and publishing mode", Grammarly can be used to proofread the paper and Mendeley can be used to add references and generate a bibliography. In the collaborative writing process, students can make use of shared Google documents, which fellow students and the teacher can feedback formatively. To support the students, the teacher can develop an online learning platform with knowledge clips made with ShowMe and (s)he can give oral feedback on written documents using Kaizena.

\section{CONCLUSIONS}

The profusion of apps and tools dedicated to supporting the (academic) writing process makes it difficult to navigate the offer, both for students and teachers. A critical stocktaking effort was necessary to chart the apps with a didactically transformative potential. The selected apps were then mapped onto a structured model of the writing process, which was extended to include "collaborative writing" and "teaching writing". The resulting map helps students and teachers alike with identifying apps and tools that usefully contribute to their (academic) writing and learning process.

\section{ACKNOWLEDGEMENTS}

I am grateful to NACV, who invited me as keynote speaker to its yearly meeting and prompted me to do the necessary research for this paper, and to dr. Sarah Haas, for allowing me to use her model and app in the developmental phase.

\section{REFERENCES}

[1] R. R. Puentedura, "The SAMR Model: Background and Exemplars," [Web log post]. Retrieved from http://hippasus.com/rrpweblog

[2] B. Cope, M. Kalantzis, "Towards a New Learning: the Scholar social knowledge workspace, in theory and practice," E-learning and Digital Media, vol. 10, no. 4, pp. , 2013.

[3] S. Haas, "Writerdev," [App]. Retrieved from the App Store (Apple).

[4] K. Walsh, EmergingEdTech. Retrieved from www.emergingedtech.com.

[5] Appsakee. Retrieved from https://www.klascement.net/apps/. 
[6] J. Lievens, C. Frijns, T. Van Daele, M. Peetermans, M. Lenaerts, L. Jacobs, B. Bergervoet, S. Van Laer, Touch2Learn. Een website over het krachtig inzetten van mobiele technologie in het hoger onderwijs. Leuven: Associatie KU Leuven. Retrieved from www.touch2learn.be

[7] T. Van Daele, C. Frijns, J. Lievens, "How do students and lecturers experience the interactive use of handheld technology in large enrolment courses?", British Journal of Educational Technology, vol. 48, no. 6, pp. 1318-1329, 2017.

[8] J. Lievens, T. Van Daele, "Touch Teach Learn. Unlocking the potential of touch enabled mobile devices for higher education," INTED Proceedings 9th International Technology, Education and Development Conference, pp. 5298-5304, 2015

[9] M. González-Lloret, L. Ortega., Technology-mediated TBLT. Researching Technology and Tasks. Amsterdam, The Netherlands: Benjamins 2014.

[10] K. Van den Branden, Task-Based Language Education. From theory to practice. Cambridge, England: Cambridge University Press, 2006.

[11] J. Lievens, "Debunking the 'Nerd' Myth. Doing Action Research with First-year Engineering Students in the Academic Writing Class," Journal of Academic Writing, vol. 2, no.1, pp. 74-84, 2012. 